\title{
The interplay between SME owner-managers and the brand-as-a-person
}

\begin{abstract}
Purpose - The objective of this paper is to investigate the largely unexplored conceptualisation of the brand-as-a-person metaphor in SMEs by examining its potential relation with the SME owner-manager, the pathways to its creation and development, and the intuitive nature of this relationship.
\end{abstract}

Design/methodology/approach - A grounded theory approach was used, and data were collected through a set of thirty-six semi structured interviews with 30 SME owner-managers in various sectors in Mexico.

Findings - The results indicate that SME owner-managers intuitively humanise their brands. The study revealed four pathways to develop the brand-as-a-person metaphor in the SME context: through 1) personality traits, 2) tastes and preferences, 3) abilities and knowledge, and 4) values, all suggesting that SMEs' brand-as-a-person metaphors are largely an extension of their ownermanagers.

Research implications - The paper presents a theoretical framework that illustrates the four pathways to the creation and development of brand-as-a-person that are derived from the brand's relationship with the SME owner-manager. The results of cross-industry semi-structured interviews are limited to a single culture context.

Practical implications - SME owner-managers should first undertake an introspective personal assessment of their intuitive and conscious decision-making, as SME owner-managers often make decisions in an intuitive way. The results suggest that they should act in a more conscious, responsible, and rational way when formulating their brand strategies.

Originality/value - This is the first study to clarify the profound influence of SME ownermanagers' personal characteristics, including personality traits, tastes and preferences, abilities and knowledge, and values, on the brand-as-a-person metaphor. This study also confirms the intuitive learning strategy formulation of SME owner-managers' branding practices and SMEs' need for a more rational approach to branding. 
Keywords: brand management, SMEs, brand-as-a-person, brand personality, brand anthropomorphisation, entrepreneurial intuition

Paper type: Research paper 


\section{Introduction}

Brands are a valuable asset for small and large organisations as they produce a bundle of benefits which enhance the relationship among the firm, its owners, its customers, and other stakeholders (de Chernatony and McDonald, 2003; Kapferer, 2004; Keller, 2001). When seeking to position a brand successfully, brand managers connect their brands with consumers through intangible aspects of the brand, such as the brand personality, as a basis for creating affinity. This aspect of brands is part of the brand-as-a-person metaphor, which includes its personality, demographics, and behaviour (Machado et al., 2019). Prior studies have shown that consumers connect with brands whose personalities are similar to theirs (Freling et al., 2011; Huang et al., 2012; Radler, 2018).

A large part of the literature on brand personality seeks to determine how to improve the brand's relationship with customers (Banerjee, 2016; Kervyn et al., 2012; Radler, 2018). However, there is little knowledge of, or research into, the extent to which brand managers have a similar connection with the brands they manage. This study seeks to describe the connection between brands and brand managers, as key decision-makers, at the time when the brand is being created and developed - that is, when the brand belongs to a small-to-medium-sized enterprise (SME), and the owner-manager has a major role in formulating the brand's personality of the brand, among other intangible elements of the brand. Therefore, this paper seeks to identify the pathways that may structure the connection between the SME owner-manager and the brand-asa-person and to reveal the nature of this connection.

In contrast to the analytical focus of a majority of research studies on brand-as-a-person, this study focuses on the management's (cf. the consumer's) perspective, thus addressing calls for additional theoretical underpinnings of this metaphor (Davies et al., 2018). This approach offers three key benefits: it helps to explain the nature of a humanising strategy that stems from the SME owner-manager's personal characteristics and narrative; as the brand-as-a-person is created and developed during the initial stages of the business, it helps to clarify the brand's origins and heritage as it becomes part of a larger organisation; and it helps owner-managers ensure that the brand-as-a-person remains true to its core values and relationship to the SME owner-manager who created and developed it. 
SME branding is at an early stage of research development. Many studies have explained the importance of brand orientation and brand identity (Hirvonen and Laukkanen, 2014; Muhonen et al., 2017), but little is known about the effect of the SME owner-manager's transitional and powerful guidance (Spence and Essoussi, 2010). Since they play an important role in many brand decisions, an owner-manager builds his or her brand using personal intuition, passion, knowledge, expertise, and personality (Dion and Arnould, 2016; Kienzler, 2017). Prior studies have suggested that SME brands become an extension of their first owners' characteristics (Mitchell et al., 2015; Renton et al., 2016; Spence and Essoussi, 2010). One study in particular makes reference that the brand becomes the personification of the SME owner-manager (Krake, 2005). To illustrate this connection, Kate Spade began designing her own handbags with a jaunty style that are considered an iconic emblem of fashion, as was Kate herself (Hanbury, 2018). SMEs' strategy formulation improves when SME owner-managers explore and make decisions using high levels of introspection, intuition, and consciousness. If strategy is intuitively formulated, it is possible to infer that brand-as-a-person is not formulated intentionally but is consciously learned, just as many other management skills are developed (Centeno et al., 2013; Mintzberg and Walters, 1985). Unfortunately, academic research on SME brands have neglected to understand the relationship between SME owner-managers and the brand-as-a-person metaphor including brand personality.

The entrepreneurship literature has sought to understand the entrepreneurs' personalities and their effect on their businesses (Holland and Garrett, 2015; Viinikainen et al., 2017; Yitshaki and Kropp, 2016). Many authors have argued that researchers should look to entrepreneurs' values and cognition as primary psychological characteristics and as signals by which to understand how they manage their businesses and formulate their vision and strategies (Tomczyk et al., 2013). The literature has suggested that the entrepreneur's personal characteristics affect his or her business, so while the entrepreneurship literature has focused on learning about the effect of the entrepreneur's personality and other personal characteristics on his or her business, the branding literature has focused on determining how the brand's personality and the customers' personality connect and how that connection can be improved. To the best of the researchers' knowledge, no study has yet analysed how the SME owner-manager's personality influences his or her brand's personality. 
This study makes two primary contributions, one theoretical and one managerial. From the perspective of theory, this study provides empirical evidence of the various pathways to the SME owner-manager's development of the brand-as-a-person metaphor. No other study captures the intuition of the SME owner-manager in creating and developing a brand-as-a-person that is close to her or his personal characteristics and that go beyond a distorted image of her/himself. Instead, as prior entrepreneurial literature has suggested, many activities of the entrepreneur are representations of herself or himself, as their activities including branding usually mirror their roles as owner-managers. This paper also offers a managerial roadmap for the development of brand-as-a-person to help SME owner-managers develop a less intuitive and more conscious strategy that matches their personal characteristics and those of their consumers. The SME owner-manager is then required to seek congruency between consumers and the brand and between herself or himself and the brand.

Since the objective of this study is to analyse brand-as-a-person metaphor from the owner-manager's perspective, the next section presents an overview of the literature on brand-asa-person metaphor, followed by a research focus section on the brand strategies used in SMEs and entrepreneurs' key traits. Then the methodology section explains the grounded theory approach used in this research. Next, the findings are presented, along with analyses of the relationship between SME owner-managers and their brand-as-a-person. Theoretical and practical discussions follow, and the paper concludes with the study's limitations and suggestions for future research.

\section{Brand-as-a-person: definition, purpose, and dimensions}

Animism (Flight and Coker, 2016; Guthrie, 1993; Nida and Smalley, 1959) and anthropomorphism (Epley et al., 2007; Tuškej and Podnar, 2018; Waytz et al., 2010) are the theoretical building blocks with which to study the brand-as-a-person metaphor (Aaker, 1997; Fournier, 1998; Davies and Chun, 2003; Gardner and Levy, 1955; Hanby, 1999; King, 1973). Animism, which is defined as "attributing life to the non-living" (Guthrie, 1993, p. 52), has also been referred to as the belief that objects acquire souls in the sense that they have a core essence similar to an ancestry or genealogy (Aggarwal, 2004). Anthropomorphism is defined as 
"attributing human characteristics to nonhuman things or events" (Guthrie, 1993, p. 52). Social psychology provides extended research on how humans anthropomorphise inanimate objects and non-human actors like supernatural beings (Epley et al., 2008; Niemyjska and Drat-Ruszczak, 2013), computers (Gong, 2008; Waytz et al., 2010b), and pets (Chartrand et al., 2008; Epley et al., 2008). With the expanded presence of brands in consumers' lives, interest has increased in how animism and anthropomorphism can improve consumer-brand interactions and relationships between the brand and the brand managers, including SME owner-managers (Herskovitz and Crystal, 2010).

Marketing researchers noted this consumer capability decades ago (Gardner and Levy, 1955; Newman 1953) and brand managers began to encourage this anthropomorphising trend by humanising their brands (i.e. by creating brand characters like The M\&M chocolate characters, Chester Cheetah, and Tony the Tiger) and consumers responded by portraying brands as humans (Aggarwal and McGill, 2012). This conceptualisation, then, can be analysed from the management and consumer perspectives. However, much of the literature on brand-as-a-person researches the metaphor mainly from the consumers' side; leaving unanswered many questions about the humanisation of brands from the manager's side.

Brand anthropomorphism is a multidimensional concept (Guido and Peluso, 2015) of which brand-as-a-person is a major dimension. Brand-as-a-person has been defined as the expression of the brand's humanistic characteristics, such as personality, values, and behaviour (Herskovitz and Crystal, 2010). A brand-as-a-person may have three key purposes: to act as a manifestation of the company, to place expectations about the type of relationship the firm has with its consumers, and to represent a group of qualities through which a customer-brand relationship can be developed (Stern, 1988).

Brand-as-a-person is also a vehicle by which a compelling and differentiated narrative is delivered that reflects the brand's values and behaviours (Herskovitz and Crystal, 2010). A favourable brand-as-a-person is one that remains true to its essence as the brand grows and develops during the business's stages of development and as the firm grows from an SME to a larger firm. Dion and Arnould (2016) suggested that brands that connect particular brandable qualities with their owner-managers' human characteristics are personafied brands. Their study 
found that firms manage their brand-as-a-person by fragmenting the various facets of a persona and by integrating these elements into a narrative at the operational and strategic levels.

Studies have found that, in larger organisations, when the CEO and his or her brand are aligned, CEOs may have a positive influence on brand value (Balmer and Greyser, 2006). Bendisch et al. (2007) recommended that this alignment should consider the flexible set of core values that emerge as business leaders shape their personal and managerial roles in response to business and personal interactions. Bendisch et al. (2013) also suggested that the CEO's media exposure influence his or her brand and that the CEO's personality and relationships are key characteristics that influence the brand. We contend that, similar to CEOs, SME owner-managers manage their brands by infusing part of their personas into their strategy and operations based on their personalities and core values. Brand-as-a-person may serve as a strategic device to assess the image of the business.

Hypothesising the dimensions of brand-as-a-person is complex because of its relative newness to branding (Aggarwal and McGill, 2012), but the literature suggests three dimensions: demographic, behavioural, and personality (Aggarwal and McGill, 2012; Epley et al., 2008; Waytz et al., 2010). A brand's demographics is related to its life cycle, just as human beings have a life cycle (Müller et al., 2013). Brands go through an ageing process, starting from their inception and first years of growth, when brands require careful management, as this stage is the basis for the brand for years to come. Brands' age is perceived, not biological, and has been linked to a wide range of factors, including the brand's managers, employees, and endorsers (Huber et al., 2013). As perceived age has been linked to personality traits (Huber et al., 2013), brands during their first years tend to be contemporary and trendy (Bontour and Lehu, 2002). When managed properly, they serve as a sound basis for their heritage and eventual history. Another demographic characteristic is brand gender which is linked directly to the dimension of brand personality (Azar, 2015) and defined as a "set of human personality traits associated with masculinity and femininity applicable and relevant to brands" (Grohmann, 2009, p.106). When measuring this dimension, studies refer to four brand genders: masculine, feminine, androgynous and undifferentiated (Grohmann, 2009). Studies on androgynous brands-those that have both feminine and masculine traits - indicate that the trait may have positive impact on brand equity (Lieven and Hildebrand, 2016). Machado et al.'s (2019) study on brand gender in social media 
showed that highly masculine or feminine brands tend to promote consumer identification with the brand and stimulate brand love. Their study also suggested that building a strong brand gender identity, whether feminine or masculine, helps consumers identify with the brands. Therefore, it is possible to conclude that a brand gender helps consumers to define and identify with it, improving brand equity.

The brand's behavioural dimension, refers to the notion that brands have interior aspects like beliefs and values, desires and preferences, intentions, free will, emotion, and consciousness (Portal et al., 2018; Puzakova et al., 2009) that create the impulse for their behaviour. The organisation's values appear to be an initial factor in constructing brand-as-a-person, as the expression of values create a sense of individuality (Simões and Dibbs, 2001). Therefore, management must control and discuss within the organisation the right values for the brand, as they are also related to the brand's personality traits (Portal et al., 2018).

Brand personality is defined as "the set of human characteristics associated with a brand" (Aaker, 1997, p. 347), a definition that many authors embrace (Aaker et al., 2001; Arora and Stoner; 2009; Avis, 2012; Sung and Tinkham, 2005) and others oppose (Azoulay and Kapferer, 2003). Key findings include the notion that brand personality shapes consumers' perceptions about a branded product when they evaluate its intrinsic product attributes (Freling and Forbes, 2005), increasing purchase intentions and improving brand attitudes (Ivens et al., 2015), consumers' inclination to cooperate with the brand (Stinnett et al., 2013), and brand trust (Li et al., 2008). Prior studies have recommended a fit between the brand's personality and that of its consumers (Huang et al., 2012). As consumers prefer brands that are congruent with their personalities, brand managers seek to build brand personalities that may help consumers identify with them (Banerjee, 2016). This study proposes a parallel situation between brand personality and that of the SME owner-manager. As SME owner-managers develop their brand personalities, they intuitively create brand personalities that fit their own. As occurs with consumers when they express themselves by purchasing a particular brand (Belk, 1988), SME owner-managers express themselves through the creation and development of their brands.

In regards to the dimensions of brand personality, they often vary (Veloutsou and Taylor, 2012). Davies et al.'s (2018) literature review finds sixteen dimensions of brand personality in twenty-one scales and suggests that only sincerity, competence, and status are dimensions across 
cultures and nations, while the rest are context-related. Thus, researchers are motivated to consider context-related elements like culture, product categories, language, and respondents in their studies (Davies et al., 2018; Raushnabel et al., 2016; Sung et al., 2015).

Research on brand personality has matured in various contexts and perspectives and a call has been raised to be tested in new areas (Freling et al., 2011). For instance, Kervyn et al. (2012) suggest that admired brands exhibit traits of warmth and competence that can be traced to employee and management behaviour. Portal et al. (2018) extends that study by developing a human brand model that addresses the relevance of employee and management behaviour and suggests that sincerity, friendliness, and capability humanise brands. As brand personality also impacts purchase intention, Freling et al. (2011) suggest that, by using three dimensions of brand personality (favourability, originality, and clarity), brand managers can develop promotional brand strategies that will impact purchase intention. Freling and Forbes, (2005) analyse multiple brand personalities and suggest this approach as an effective brand strategy for reaching several consumer targets. Finally, Veloutsou and Taylor (2012) examine brand personality in the business-to-business (B2B) context and find that the brand personality must fit that which its customers expect. In particular, customers seem to appreciate the brand as a business partner when it is seen as reliable, responsive, trustworthy, and knowledgeable. Therefore, brand personality and other brand-as-a-person characteristics must be aligned with those of the customer and other brand stakeholders. While many studies assist in clarifying how brand personality works for the consumer, few studies look at brand personality from the management side. In particular, there is still a need to determine whether this dimension is present in SME brands and to identify its relationship with SME owner-managers.

Congruity between the self and the brand is an important consideration in research on brand-as-a-person. It refers to the notion that anthropomorphised brands reflect consumers' perceptions of themselves (Guido and Peluso, 2015). Consumers may select brands that they perceive as congruent with their views of themselves (Sirgy, 1982) and may help them express their actual, ideal, or social selves (Malhotra, 1988; Parker, 2009; Randhawa et al., 2015). Selfbrand congruity increases brand preference and brand loyalty (Puzakova et al., 2009). Studies show that, when consumers perceive congruity between their self-concepts and a branded product, they imbue personality traits into that product (Belk, 1988; Escalas and Bettman, 2005; 
Lam et al., 2013). Many consumers identify with their brands' symbolic associations (Maehle and Shneor, 2010). This study proposes that a similar process occurs when an SME ownermanager creates and develops his or her brand-as-a-person, in the sense that there is congruity between the brand and the owner-manager's self-concept.

\section{Research focus: The SME context}

From the beginnings of SME branding research in 2005 and after more than a decade of research, there is evidence to suggest that SMEs' performance benefits from brand management (Agostini et al., 2015). While some studies have suggested that brand management is a secondary task for SME managers (Krake, 2005), others have suggested that branding is an essential activity for building brand reputation, marketing a product/service, and increasing profit (Spence and Essoussi, 2010; Törmälä and Gyrd-Jones, 2017). These contradictory results may be due primarily to the personal position that the SME owner-manager may take toward marketing and branding in particular and to how the SME owner-manager makes decisions.

One of the main differences between managing SMEs and managing larger organisations is that, in smaller firms, decisions tend to be informal and to be taken by the SME ownermanager (Jones and Macpherson, 2006). As the organisation continues to grow and more members participate in decision-making, the owner-manager's influence decreases, especially when the firm begins a process of institutionalisation and formalises many corporate processes and structures so decisions are taken less intuitively and more rationally.

Many studies on SME branding have given importance to two fundamental concepts: brand orientation (Hirvonen and Laukkanen, 2014; Hirvonen et al., 2013; Renton et al., 2016; Wong and Merrilees, 2005) and brand identity (Muhonen et al., 2017). However, little is known about the effect of the SME owner-manager's powerful and transitional guidance (Spence and Essoussi, 2010). In the SME's early stages, the owner-manager directs the brand development process either as a static, purposeful activity or as an iterative process among internal and external stakeholders.

Brand management researchers have found that while brand managers in larger organisations formulate and track brand elements with respect to brand personality to rationally suit consumer's identity (Branaghan and Hildebrand, 2011), SMEs' brand elements are 
developed through owners' involvement and passion and their controlling influence (Centeno et al., 2013; Horan et al., 2011; Muhonen et al., 2017). Passion is a key characteristic of entrepreneurial activities because SME owner-managers identify themselves with these activities as they invest heavily in energy, time, and financial resources (Cardon et al., 2009; Powell and Baker, 2014). During the SME's first years, its owner-manager imbues her or his personal values and ideas into the firm to give it and its brand an identity and differentiation that often remain after she/he has left the firm (Blombäck and Brunninge, 2013).

When analysing key aspects of SMEs, prior studies have shown that managers' personalities influence some managerial practices, especially under the conditions of uncertainty that are common to SMEs (Kienzler, 2017). Research has also found that, in particular, managerial style, salespeople, and brand personality should be aligned (Gammoh et. al., 2014), especially considering that SME owner-managers are usually their firms' main salespersons. The owner-managers directly influence and decide how their brand is developed (Centeno et al., 2013; Christmann et al., 2016; Mitchell et al., 2015). Since SME owner-managers have an important role in deciding on the brand activities, the brand may be built on their personalities (Krake 2005; Muhonen et al., 2017). For SMEs, the creation of intangible brand elements like brand-as-a-person leads to lasting key differentiators, as opposed to functional elements, which are frequently temporary (Stride and Lee, 2007). Muhonen et al. (2017) reveal that brand values, as part of the brand, are an important driver of brand vision, brand positioning, and performance. Unlike branding activities in larger organisations, which are typically undertaken by a marketing department, an SME's branding activities are embedded throughout the entire firm (Simões and Dibb, 2001).

In part because of SMEs' lack of resources, SME owner-managers' intuition and creativity seem to influence SMEs' brand-building (Reijonen, 2010). They develop new models of communication with their customers (Centeno and Hart, 2012; Lory and McCalman, 2002), such as making the owner-managers the key spokespersons for public relations and advertising activities and sometimes become the 'celebrity' of their brands (Centeno and Hart, 2012). Their engaging in publicity increases brand knowledge at a minimum cost (Agyapong et al., 2016; Verhees and Meulenberg, 2004), and acting upon their unplanned and intuitive decisions. 
Prior studies on entrepreneurship have proposed that many activities run by SME ownermanagers are based on the founder's identity, defined as "the set of identities that is chronically salient to a founder in her or his day-to-day work" (Powell and Baker, 2014 p. 1413). Entrepreneurship is a highly complex activity because it is a job the entrepreneur defines himself or herself in which the entrepreneur's personality appears to be a main construct (Frese and Gielnik, 2014). Owner-managers use their businesses as platforms from which to express their social and personal identities. Therefore, of importance to the study is the identification of the entrepreneur's characteristics, including their personalities as a major determinant of SMEs' success (Elmuti et al., 2011; Kozubíková et al., 2015; Owens et al., 2013) and strategies (Odoom et al., 2017), especially in relation to the creation and development of the brand-as-a-person metaphor. The brand becomes a symbol and a platform for establishing brand authenticity, as reflects the owner-manager's personality and value system (Blombäck and Brunninge, 2013).

Particular personal characteristics, such as knowledge and expertise, personality traits and emotions, abilities, tastes and preferences, and entrepreneurial values, may influence the types of strategies entrepreneurs adopt in their businesses (Wijewardena et al., 2008). Knowledge offers cognitive structures that determine how entrepreneurs interpret new information, so SME ownermanagers interpret and direct their businesses based on acquired knowledge and expertise (Shane, 2000). The more of their skills and tacit knowledge SME owner-managers bring to the management of their firms, the better it is for their businesses (Frese and Gielnik, 2014).

SMEs' strategy formation and planning differ from those of larger organisations. While strategy is typically defined as the long-term direction and scope of an organisation (Hunt and Morgan, 1995), SMEs' strategy formulation is less rational, more short-term, and oriented toward intuition, experimentation, exploration, instinct, and learning (Centeno et al., 2013; Mintzberg and Waters, 1985). There is far less empirical research on intuition in decision-making than there is on rationality in decision-making (Elbanna et al., 2013). Intuition has been defined as an ability acquired from years of experience, internal introspection, and knowledge (Adriotti, 2010) to make decisions based on one's "feelings" or "gut." Four situations in particular promote intuitive decision-making: high levels of uncertainty, rapid changes in consumer composition and preferences, scarce access to historical data when faced with new conditions, and limited availability of facts (Wiratmadja et al., 2016; Zacca et al., 2017). SME owner-managers 
continually face these situations. Importantly, SMEs' strategy formulation improves when SME owner-managers explore and also learn to make rational-based decisions using higher levels of introspection and consciousness. SME owner-managers acquire this mind set through experimentation, rationalisation, and learning (Endres and Woods, 2010; Oguz, 2000), which also helps them with entrepreneurial learning. At their early stages, SMEs' learning is experiential, often unconscious, informal, and sometimes unintentional (Cope and Watts, 2000; Politis, 2005; Wang and Chugh, 2014). Prior studies have shown that SME owner-managers often manage their activities through symbols that represent their role as managers (Castrogiovanni, 1996). This study argues that a brand is such a symbol, as it establishes a framework and structure for the firm's development (Blombäck and Brunninge, 2013) and helps to legitimise the firm's and the owner-manager's persona.

If strategy is intuitive in SMEs, it is logical that the strategy behind brand-as-a-person is similarly developed. SME owner-managers may not intentionally formulate brand-as-a-person, although they may learn how to develop their brand strategy through this process. If SME brand strategy has a learning formulation based on intuition and unconsciousness, it is reasonable to conclude that SME owner-managers develop their management skills by first becoming aware of such strategy formulation and then consciously monitoring their brand decisions.

Considering the SME context, this study seeks to determine the nature and possible structure of the connection between the SME owner-manager and the brand-as-a-person. Based on this connection, this research can infer that SME owner-managers create their brands by intuition and, in so doing, create them in close proximity to their personal characteristics. As how a firm manages its brand is a key part of the firm's positioning success, this study seeks to provide a rational, rather than an intuitive, roadmap for branding in the SME context.

\section{Research Methodology}

Previous studies have called for qualitative research to determine how SME ownermanagers develop business strategies (Berthon et al., 2008; de Massis and Kotlar, 2014, Eriksson and Kovalainen, 2016; McCarthy, 2003) and to explore the changing and evolving context of marketing (Gummesson, 2005). The present study uses the grounded theory approach (Strauss and Corbin, 1990) to explore the brand-as-a-person metaphor and its relationship to SME owner- 
managers. Such authors as Glaser and Strauss (1967) and Gehpart (2004) recognise grounded theory as a practical method for conducting research that focuses on the interpretive process by analysing the production of the meanings and concepts social actors use in real settings. The procedures of grounded theory are designed to develop a well-integrated set of concepts that provide a thorough theoretical explanation of a social phenomenon. Grounded theory should explain as well as describe, and may also import some degree of predictability but only with regard to specific conditions (Corbin and Strauss, 1990).

Grounded theory offers opportunities for theory-building in areas in which there is limited current research or new insights are needed (Glaser and Strauss, 1967). The aim, like those of other qualitative research methods, is to develop new insights into phenomena in areas about little is known (Matteucci and Gnoth, 2017). Charmaz (2011, p. 361) considered grounded theory to be "an iterative, comparative, interactive, and abductive method" with which researchers can develop their own groupings instead of polishing current ones (Bryant and Charmaz, 2007).

Gibson and Hartman (2014) emphasised five key principles of grounded theory: openness, explanatory power, generation vs. justification, theory structure, and the research process. Openness relates to research that is guided by the research questions that remain open throughout the examination. Explanatory power involves research that is trustworthy and pertinent to all or some group of people. Grounded theory focuses on generating insights or knowledge about a phenomenon, not on justifying pre-existing notions. Theory structure involves a group of theoretical propositions that are connected to core groupings that need to be explained and linked to other groupings. The fifth principle relates to a research process that is responsive and iterative, consisting of data coding and interpretative stages.

Data for the study were drawn mainly from thirty-six semi-structured interviews-thirty during the first phase of exploration and six second phase interviews in which results were presented and confirmed with SME owner-managers who participated in the first phase of interviews. Interviews averaged between fifty and sixty minutes. During the initial stages of brand personality research, individual interviews are a common technique to elicit items and personality traits (Das et al., 2012). Semi-structured interviews provided a framework to keep the discussion on topic while allowing the flexibility to incorporate appropriate deviations and explore each owner-manager's relationship with his or her brand. Curran and Blackburn (1994) 
recommend this type of interview for interacting with SME owner-managers. The interviews were built around seven questions: How did you start your business? How was it created? How was it developed? What do you consider to be the business's functional/performance characteristics? What are its benefits? What are its values and beliefs? If the brand were a person, what personal characteristics would stand out most clearly?

The first interview phase was mainly exploratory, while the second phase was confirmatory, as SME owner-managers were asked to reflect on their previous responses while validating and confirming preliminary findings. Both of the interview phases ended when they reached theoretical saturation (Strauss and Corbin, 1998). Following Miles and Huberman's (1994) recommendations, interviews were not used only as instruments with which to gather data but also as means to explain the relationship between SME owner-managers and brand-as-aperson. The main source of information came from the interviews.

The rich data from the interviews were complemented with evidence from supplementary sources like observations that emerged from visiting offices to conduct interviews, print advertising, webpages, and publicity materials, including articles and books written by ownermanagers and those published by the media and SME trade organisations. These additional sources helped to match information derived from the interviews with communications from other sources, thereby strengthening the quality of the research. Table 1 provides a summary of the main supplementary research sources used for the analysis of the pathways of brand-as-aperson.

\section{TABLE 1 ABOUT HERE}

SME owner-managers, as key informants, were interviewed to achieve the objectives of this research (de Massis and Kotlar, 2014; Rode and Vallaster, 2005). In cases that had more than one owner-manager, the one owner-manager with the most involvement in the business and decision-making was interviewed. The Mexican government's official definition of SMEsorganisations with 10 to 250 employees and relatively small market presence that are independently owned and managed by their owners — was used to identify suitable firms. 
The units of analysis are the interplays between the interviewed SME owner-managers and the brand. A list of SMEs was developed from searching SME organisations, articles written in newspapers and magazines about SME brands, tradeshow directories, online trade organisations, development banking institutions, and Mexico's Economic Ministry directory. Once a list was created, the SMEs were selected to approach for interviews based on whether they had a brand, a current webpage, and an email address. The SMEs on the resulting list were also evaluated to determine whether they were currently involved in brand communications (brand website; advertising, and articles in newspapers, business publications, and consumer magazines), sales, packaging design, distribution, and new product development, all of which were evaluated to determine whether they were targeting a particular market. The presence of these activities helped to frame the study theoretically (de Massis et al., 2012; Silverman, 2005).

A list of candidate SMEs was developed, and a letter was sent to each one. Of those who responded and were actively involved in brand activities were invited to participate in the study. The final group comprised a wide range of consumer product and services businesses representing the top five economic sectors of Mexico's gross domestic product, including manufacturing, services and retail. The SMEs were from Mexico's four largest cities: Mexico City, Guadalajara, Monterrey, and Toluca. Appendix 1 provides an overview of the general descriptors of the SMEs. Of the thirty SME owner-managers, nine were females; twenty-five had an undergraduate and two had double degrees ( 8 in engineering, 9 in business, 4 in art sciences, 3 in health sciences, 3 in marketing, and 2 in finance); and seventeen had prior experience with the SME's product/service category.

All interviews were transcribed and systematically open coded by defining and describing both theoretical and data-driven codes (Boyatzis, 1998; Eriksson and Kovalainen, 2016). Data were analysed using thematic coding (Boyatzis, 1998) following a concurrent process of data reduction, data displays, conclusion-drawing, and verification (Miles and Huberman, 1994). Data analysis used a combination of NVivo, which is one of the most popular Computer Assisted Qualitative Data Analysis Software (CAQDAS) for qualitative research, to organise and code all transcripts systematically, along with various writing and research tools to capture the thoughts driven by the research and to facilitate and stimulate the analytic insights. The writing tools were research memos created for each of the transcripts; a research journal, which was written 
throughout the implementation of the research design; and diagrams and tables, which assisted in the tracking and expression of connections and themes. Each tool was either critical or complementary, depending on its importance in each of the stages of data analysis. Used in conjunction, these tools helped to guide the emergence and development of the main themes (Gummesson, 2005). NVivo in particular helped to compare and contrast codes systematically within and among the transcripts, to distinguish the patterns that emerged from the data input, and to work with a large amount of data in an aggregate and iterative fashion.

The iterative comparisons of data, a principle of grounded theory, was at the centre of this recurrent research process. Following Glaser and Strauss (1967) during the first exploratory phase, interview 1 was compared to interview 2, then interview 2 to interview 3, then interview 3 to interviews 1 and 4, and so on until each interview was compared to all others and patterns emerged. After each set of five interviews, comparisons were made between sets until the final set was complete. This method helped to structure individual findings by interview as well as overall findings and patterns derived from the six sets of five interviews. A similar process was followed during the second confirmatory phase.

In grounded theory, data collection and analysis involve constant iteration and research is complete once theoretical saturation has been reached - that is, when new theoretical insights and new properties of key categories no longer emerge during the theory-development process (Glaser and Strauss, 1967). Following Goudling (1998) and Charmaz (2006), a coding procedure is followed by open/initial coding, which involved "breaking down [the] data into distinct units of meaning"; focused coding, which required selecting the most useful analytical codes; and axial (theoretical) coding, which involved making links between codes to develop categories and identifying the conditions that give rise to the categories, their context, and their connections and outcomes. Relating these categories to each other led to research propositions.

Meanings emerged as themes were compared and contrasted, and patterns were revealed. Table 2 summarises the main theory and data driven codes used in the final stage of the analysis.

\section{TABLE 2 ABOUT HERE}


The set of theory-driven codes shown in Table 2 led to identification of the key theoretical elements from the study's interviews (Aaker, 1997; Krake, 2005; Muhonen et al., 2017). As other authors recommend, a qualitative analysis is useful in the early stages of exploration of new dimensions and items of brand personality (Das et al., 2012). The set of data-driven codes emerged from rich information that made reference to brand-as-a-person. In the final stage of analysis, the presence of brand-as-a-person was confirmed, as was the various pathways of the creation and development of brand-as-a-person and the nature of the connection between the SME owner-manager and the brand-as-a-person.

\section{Results}

\section{The pathways for the creation and development of brand-as-a-person}

Four pathways emerged when the analysis revealed that, rather than making a rational decision about how to develop a brand-as-a-person that was consumer-oriented, most of the interviewees expressed intuitively the characteristics of their brand-as-a-person in relation to their own characteristics. As the personal characteristics of SME owner-managers and those of the brand-as-a-person were compared and contrasted, a pattern emerged between the two that suggested that SME owner-managers used distinctive pathways to create and develop the brandas-a-person. The SME owner-managers did not consciously relate their own characteristics with those that describe their own brands. During the first exploratory phase, conversations about their own characteristics emerged spontaneously during the interviews without the interviewees' being asked directly about these characteristics. When this finding was presented during the second phase of interviews, the interviewees reported an agreement that the descriptions of the brand-asa-person were also descriptions of themselves. This finding also supports prior studies' suggestions that the brand reflects some aspects of the owner-managers' self-concepts, resulting in the owner-manager's identification with the brand and a subsequent 'inter-personal' relationship with it (Guido and Peluso, 2015; Randhawa et al., 2015).

The main four pathways used by the SME owner-managers are humanistic associations: personality traits, tastes and preferences, abilities and knowledge, and values. Each of these four pathways helped to create and develop the brand-as-a-person in such a way that they may 
contribute to the establishment of brand differentiation and brand authenticity based on the personal manner in which it was built (Blombäck and Brunninge, 2013).

\section{The pathway through brand personality}

Brand personality is the pathway that the owner-managers prescribed most often. The findings also suggest that these expressions of brand personality refer to the daily lives of the owner-managers in terms of their conduct and how they think and feel. This finding supports previous studies' suggestion that personality is a pattern of behaviour, thoughts, and feelings (Lin, 2010). Brand personality was interpreted as the way the SME owner-managers express how they operationalise their day-to-day activities. This finding also supports the notion that entrepreneurs are usually pragmatic and action-oriented and that the owner-manager's personality influences his or her managerial practices (Kienzler, 2017). Table 3 provides examples of this finding.

\section{TABLE 3 ABOUT HERE}

Most of the SME owner-managers referred to the gender of the brand-as-a-person as the same as their own gender, which is a central part of the SME owner-managers' self-concept. However, other brand personality characteristics indicated that the brand-as-a-person's age was not linked to that of the owner-manager but was a perceived age, often expressed as "being young," "young and dynamic," "young and energetic," "young and contemporary," and "young and trendy." This finding suggests that age is linked to an ideal self-concept and supports prior studies' findings that age is an important demographic variable that is not related to a biological age so much as a perceived age (Müller et al., 2013). This finding also suggests that the SME owner-manager believes that the brand has a future ahead and is optimistic about it (Bontour and Lehu, 2002; Kaplan and Warren, 2010).

Many of the key personality traits of the SME owner-manager as an entrepreneur were also given to the brand-as-a-person, including "passionate," "tough," and "hard-working." 
Passion is a key trait of entrepreneurs, as it gives identity and meaning to SME owner-managers' self-concepts (Powell and Baker, 2014). Passion also describes entrepreneurs who take risks, seek change, and compete aggressively in the market (Antonic et al., 2015; George and Marino, 2011).

\section{Pathway through tastes and preferences}

The tastes and preferences pathway is expressed through the SME owner-manager's tastes and preferences. SME owner-managers selected their businesses based on their preference for a particular market. The findings also show that antecedents to this pathway may include the ability to find a business opportunity, as they have usually a clear and rational decision-making approach to starting a business. For example, one SME owner-manager's preference for football (soccer) dates back to his teenage years, and his interest pulled him toward working in this sport (B13). When he described his brand-as-a-person, he reported it was someone who loved soccer. Another SME owner-manager who enjoyed being with children decided to open a childhood development pre-school (B3). Her brand was someone who cared about children's development. Another SME owner-manager, a medical doctor, was keen on helping overweight people, so he launched a homeopathic line of diet products to help people lower their weight (B5). He described his brand as someone who was concerned about today's obesity crisis. B22 had been conscious of maintaining good health, especially in terms of food, when he decided to start his company, so he started a restaurant with natural and organic produce and named his brand The Good Earth. A designer with interest in his children decided to build his company around educational toys that combined beautiful design with learning functionalities (B20). In particular this pathway seemed to address how owner-managers discover an opportunity to build their business and brand.

The identification of the tastes and preferences pathway sees support from previous research that has found that SME owner-managers build their businesses at a personal level so the businesses are congruous with their tastes and preferences (Guido and Peluso, 2015; Puzakova et al., 2009; Wijewardena et al., 2008) This finding also suggests that, just as consumers identify with their perceptions of the brand's congruity with their self-concepts (Lam et al., 2013), SME owner-managers develop the brand-as-a-person to be congruous with their own tastes and preferences. 


\section{The pathway through skills and knowledge}

Findings on the skills and knowledge pathway support the construction of brand-as-aperson. This finding helps to secure the future of the business by ensuring the brand-as-a-person is imbued with the right skills and knowledge to encounter challenges in market conditions. The extant literature on entrepreneurship refers to the relevance of entrepreneurial capabilitiespersonal skills, abilities, and knowledge — because they determine the growth and success of their businesses (Oyeku et al., 2014). As Frese and Gielnik (2014) suggest, the more of their skills and tacit knowledge SME owner-managers bring to the management of their firms, the better it is for their businesses. This finding reveals that SME owner-managers are keen about extending and 'armouring' their brand-as-a-person with abilities and knowledge, so they can perform better in the market:

"...the brand is very knowledgeable; he knows the tricks, he knows the keys to saving, how to make things easier, how to benefit from technology, how to find a way in the communications industry." (interviewee B4, who holds an undergraduate degree in communications engineering and has many years of experience in the field)

"... the brand-as-a-person is a medical doctor; he knows about looking after his patients, and he knows what works to help them out, improve their condition, and decrease their obesity ...." (interviewee B5, who holds an undergraduate degree in medicine and whose entrepreneurial project was sponsored by his university while he was a student)

"The brand knows about fashion; she analyses the latest trends in clothing. In many cases, she sets a fashion, she has always been interested and knows about design, colours, lengths..." (interviewee B20, who has consistently followed fashion designs, and was told at school that she was the most fashionable in the class.

"... the brand is someone who is well-known for being an expert on spices and knows where to buy the best spices at a good price...." (interviewee B26, who was about to publish a book about spices around the world)

"... the brand is someone who knows what to do and what not to; he knows its limitations ...." (interviewee B27, who had difficulty learning how to compete against larger brands in the food industry and through his experiences discovered how to compete with a small brand)

"... the brand knows about design and how to combine the latest trends in jewellery with ancient civilizations' energies...." (interviewee B30, who is a designer who is knowledgeable about the Mayan civilisation) 
This pathway is sustained by intuitive decision-making. As the literature has suggested, intuition is based on experience and knowledge (Wiratmadja et al., 2016). This pathway is particularly important to SME owner-managers, who are usually pressured to achieve results that are usually driven by skills and knowledge (Zacca et al., 2017). Therefore, it is likely that, the more experienced the SME owner-manager is, the more intuitive her or his decision will be in giving the brand-as-a-person appropriate skills and knowledge to compete in the marketplace.

\section{The pathway of values}

The values pathway of the brand-as-a-person is driven by the SME owner-manager's personal values. This finding supports prior studies' suggestion that values precede the brand associations developed by SME owner-managers (Spence and Essoussi, 2010) and are closely and personally linked to those owner-managers (Krake, 2005; Muhonen et al., 2017). In addition, as research suggests, brand values are key drivers of brand vision and positioning (Muhonen et $a l ., 2017)$ especially during the first years of the business. The owner-manager's personal values, vision, and philosophy help in establishing and aligning the business and the brand (Gammoh et al., 2014), especially when the owner-manager is doing long-term planning. Table 4 offers some examples of this finding:

\section{TABLE 4 ABOUT HERE}

\section{The nature of the connection between the SME owner-manager and the brand-as-a-person}

When informants were enquired about brand-as-a-person, only one of the SME ownermanagers had rationally formulated the brand-as-a-person metaphor for a brand, while the rest had never heard the term, although they had little difficulty verbalising and expressing their brand-as-a-person. These spontaneous expressions were rich in humanistic associations, suggesting the intuitive nature of the humanisation of their brands. These intuitive expressions support prior studies that suggest SME owner-managers manage their brands in their minds and with intuition, rather than in writing and consciously (Centeno et al., 2013; Mintzberg and 
Waters, 1985). Many SME owner-managers used their intuition, perhaps because of their conditions of uncertainty that are typical with new businesses, including lack of information and the absence of a co-decision-maker (Wiratmadja et al., 2016).

During the interviews, SME owner-managers expressed without noticing the use of the possessive pronoun " $m y$ " or the personal pronoun " $I$ " when they were referring to their brands. This type of verbalisation was as if they were the brand themselves. This finding indicates that at an unconscious level there was a strong connection that intuitively each SME owner-manager seemed to personified the brand, as indicated in the following comments:

"I have to renew myself by developing new products year after year" (interviewee B1)

"I have come to stay.... Some clients may say, 'I have seen you somewhere'..... They may be confusing me with some other brand...." (interviewee B2)

"That is what differentiates me from the rest of the brands; I am small... . They like me because I am high-quality; that's what differentiates me from the rest." (interviewee B8) "I knew that I had no brand image." (interviewee B9)

The finding of the strong connection between SME owner-managers and their brands supports prior studies on the influence of SME owner-managers' intuition during brand-building activities (Centeno et al., 2013; Reijonen, 2010). The SME owner-managers in the second phase reported that they also realised spontaneously that many of the descriptions they had given about their brand-as-a-person in the first phase were actually their own personal characteristics. They reacted to this realisation positively and expressed that this "person" was linked to themselves; as one interviewee put it, they were the sole creators and developers of their brands through "gutfeeling and with a lack of market data and marketing research". The findings in general and in particular provoked significant interest, leading SME owner-managers to indicate their desire for a similar study specifically for their own brands:

"Now I can see how clear the brand expresses many facets of who I am." - B3

“I wouldn't have thought so many characteristics of myself are in my brand.”-B113.

The finding extends prior studies that have suggested that brands mirror SME ownermanagers through their personalities and other personal characteristics (Blombäck and Brunninge, 2013). The brand-as-a-person is the brand element SME owner-managers use to 
reflect their personal characteristics in such a way that the brand-as-a-person personifies them. This finding extends the argument that the brand is linked not only to the SME owner but, as many authors have argued, that it is linked to the owner-manager. In this case, the brand-as-aperson in linked to the SME owner-manager.

While SME owner-managers intuitively develop their brands as brand-as-a-person, it must also match consumer preferences to establish differentiation, positioning, and reputation in the marketplace, which requires a rational, not an intuitive, approach (Arora and Stoner, 2009; Freling and Forbes, 2005; Veloutsou and Guzmán, 2017).

\section{Theoretical contribution}

The present study contributes to the extant literature on SME brand management in several ways and in relation to the influence of the SME owner-manager on the brand-as-aperson metaphor (Dion and Arnould, 2016; Odoom et al., 2017). First, it demonstrates empirically the presence of the brand-as-a-person in SMEs. It offers a conceptualisation of the brand-as-a-person by acknowledging the various paths by which the SME owner-manager may take in the creation and development of the metaphor. In doing so, the study demonstrates the congruence between the two. This study also reinforces that the entrepreneurial activity of SME brand management is guided by the leading role of the entrepreneur in a highly complex, selfdefined job based on aspects of his or her self-concept (Frese and Gielnik, 2014). To the best of the researchers' knowledge, this is the first study to highlight the interplay between SME ownermanagers and the brand-as-a-person metaphor. Academic research on SMEs should consider that personality traits, abilities, and values imply a particular style of management and strategy formulation (Kienzler, 2017) and address the extent to which SME owner-managers are involved in the creation and components of particular brand strategies, such as brand-as-a-person. By exploring the presence of brand-as-a-person and the possible relationship between SME ownermanagers and their brands, this study offers a sound explanation of how SMEs' brand strategies are developed.

The study extends the conceptualisation of the self of SME owner-managers particularly during the humanisation of the brand (Davies et al., 2018; Portal et al., 2018). The research found that particular characteristics of the SME owner-manager are transferred to the brand. When this 
transferability occurs, the brand-as-a-person is better align with the SME owner-manager (Dion and Arnould, 2016). The more pathways the owner-manager uses in the creation and development, the more fully humanised in brand-as-a-person. This study suggests that, when consumers choose particular brands because they perceive them as congruent with their selfconcepts (Parker, 2009; Randhawa, 2015; Sirgy, 1982), it is similar to when SME ownermanagers develop brand-as-a-person by creating congruency between their self-concepts and the brand-as-a-person metaphor.

As happens with many brands, SME brands must be aligned with consumers' expectations in order to forge a relationship with them (Flight and Kesha, 2016; Fournier, 1998). In such case, brand-as-a-person is aligned with both the SME owner-manager and consumers. Alignment with the SME owner-manager means that the brand is empowered and driven by the SME owner-manager's passion and commitment (Centeno et al., 2013; Horan et al., 2011; Muhonen et al., 2017). Alignment with the consumers means that the brand matches consumer preferences and purchase intentions (Avis, 2014; Flight and Kesha, 2016). By taking a more rational approach, the SME owner-manager protects the firm from major competitors and market fluctuations. The research proposes a more rational than intuitive approach to developing brandas-a-person. In this sense, the study proposes that even if the brand is aligned with the SME owner-manager, if it is not aligned with consumers, the brand will not build a relationship with them and may fail in the marketplace. The study falls short of establishing that the brand-as-aperson develops as strong a connection with consumers as the owner-managers do. Ownermanagers may need to look into other elements of the pathways in the creation and development of brand-as-a-person to include some aspects of the consumer's self-concept and to add more rational decision-making to build stronger connections with consumers. Brand-as-a-person may serve also as a device to evaluate the image of the SME.

By analysing brand-as-a-person, the study expands the literature's exploration of the connection between SME owner-managers and their brands (Renton et al., 2016). This study illuminates the close and intuitive nature of that relationship, contending that brand-as-a-person is driven by the SME owner-manager, as prior studies also suggest (Krake, 2005; Muhonen et al., 2017; Wijewardena et al., 2008). Specifically, this study proposes four pathways in the creation 
and development of brand-as-a-person: brand personality, tastes and preferences, skills and knowledge, and values.

This study suggests that SME owner-managers humanise their brands intuitively because they are not consciously aware of this formation. This finding confirms that, unlike brand managers of larger organisations, SME owner-managers employ non-traditional, ad hoc approaches to formulate their brand strategies (Reijonen, 2010). In this sense, even when the SME owner-managers were unfamiliar with the brand-as-a-person metaphor, they could express rich descriptions of their brands as if they understood brand-as-a-person intuitively. This research supports other studies' findings that SME owner-managers explore and make decisions at a subconscious level, and that they must learn from their experiences before advancing to a more rational, conscious level (Endres and Woods, 2010; Oguz, 2000). The SME brand literature holds that experimentation and learning take place as SME owner-managers question, introspect, and become conscious of the need to formulate strategy (Centeno et al., 2013; Reijonen et al., 2012; Wang and Chung, 2014).

The research also suggests SME owner-managers can use the various pathways to the creation and development of their brand-as-a-person according to the degree of intuition and rationality that guides their decisions about the business and its brand development.

\section{Managerial implications}

When entrepreneurs create and develop a brand as part of their entrepreneurial activities, they are involved in a self-defined job that involves their personalities and other personal characteristics (Frese and Gielnik, 2014). Therefore, when they are particularly interested in moving from an intuitive to a rational approach to creating brand-as-a-person, they should follow a managerial roadmap to help them establish a systematic process in the enterprise. As depicted in Figure 1, SME owner-managers should be conscious of the human characteristics already given to their brand-as-a-person and undertake a personal assessment of not only their own personality traits but also their abilities and knowledge, tastes and preferences, and values as to become more aware of her/his personal characteristics. 


\section{FIGURE 1 ABOUT HERE}

SME owner-managers should use what they know about their consumers to analyse their brands. This exercise will offer insights into the characteristics already established intuitively in their brand-as-a-person. In addition, being conscious of the various pathways that lead to the creation and development of brand-as-a-person and how consumers interpret these pathways can help SME owner-managers determine whether brand-as-a-person is suitable for consumers.

A conscious questioning has the purpose of detecting and prioritising the components established in each of the four pathways to brand-as-a-person as a way to evaluate and assess the degree of intuition used. Such assessment will help SME owner-managers to move from an unconscious, intuitive formulation of brand strategy to a more rational approach. SME ownermanagers should also consider seeking support from key brand stakeholders to discuss brand strategy and how the brand aligns with consumers so their brand-as-a-person can be redefined with a more rational orientation toward consumers. For instance, SME owner-managers could conduct meetings with collaborators to discuss whether the current brand-as-a-person is suitable for fully exploiting their firms' competencies. These discussions should also consider how to improve firms' performance in their markets by redefining brand-as-a-person. SME ownermanagers should also consider participating in coaching programmes that would assist the SME owner-managers in bringing some of their intuitive brand strategies to a more conscious level, enabling more rational formulation of their brand-as-a-person.

Exercises in which SME owner-managers and brand collaborators discuss brand-as-aperson may support entrepreneurial learning processes and help to develop more conscious approaches to formulating brand strategy. For instance, as Machado et al. (2019) suggested, SME owner-managers may want to develop a well-defined brand gender to help consumers identify with the brand. In the end, this process may help SME owner-managers align the SME ownermanager's characteristics with those of consumers by replacing the initial intuitive approach with 
a more rational approach to establishing their brand-as-a-person. To conclude, as the SME owner-manager establishes the firm, congruity between the SME owner-manager's personal vision, values, and philosophy and those of the firm, the brand, and the consumers is needed (Törmälä and Gyrd-Jones, 2017). The organisation must continually reinterpret and execute this congruity in later years, basing its brand's path forward on its brand heritage (Pecot et al., 2018).

\section{Limitations and Future Research}

This study is not without limitations. This is a qualitative exploratory study, and future research should test empirically the results presented across a wider variety of participants. As this study is the start of the exploration of brand-as-a-person in the context of SMEs, theory must be developed to address how brand strategy moves from an intuitive/unconscious to a rational/conscious level. Future research may draw on the entrepreneurial orientation and learning literatures to help fill many of the gaps in this area of branding, particularly regarding the close relationship between the SME owner-manager and his or her brand-as-a-person.

As prior studies have suggested, culture is an important ingredient in entrepreneurial activity (Frese and Gielnik, 2014). As this study was undertaken in one cultural context, other studies could analyse the cultural factors in entrepreneurship and their effect on brand-as-aperson. Some cultural factors worth considering are the level of assertiveness, rationality vs. emotion, tolerance for ambiguity, values and personality traits, together with how these factors impact brand-as-a-person. This study analysed brand-as-a-person from the perspective of the organisation, but it offers no indication of how consumers perceive it. Therefore, future studies could include the consumer perspective to validate whether (and how) consumers perceive the relationship between brand-as-a-person and SME owner-managers.

Aside from the major influence of SME owner-managers, future research could expand the scope of this study by including the dynamic group of independent network actors that perform direct branding activities in SMEs (suppliers, partners, funding agencies, other firms, non-profit organisations or governmental bodies) — that is, the branding pool (Mäläskä et al., $2011 \mathrm{a}, 2011 \mathrm{~b})$.

\section{Declaration of Conflicting Interests}


The author(s) declare no potential conflicts of interest with respect to the research, authorship, and/or publication of this article. 


\section{References}

Aaker, J.L. (1997), "Dimensions of brand personality", Journal of Marketing Research, Vol. 34 No. 3, pp. 347-356.

Aaker, J. L., Benet-Martínez, V. and Garolera, J. (2001), "Consumption symbols as carriers of culture: a study of Japanese and Spanish brand personality constructs", Journal of Personality and Social Psychology, Vol. 81 No 3, pp. 492-508.

Aggarwal, P. (2004), "The effects of brand relationship norms on consumer attitudes and behavior", Journal of Consumer Research, Vol. 31 No. 1, pp.87-101.

Aggarwal, P. and Mcgill, A.L. (2012), "When brands seem human, do humans act like brands? Automatic behavioral priming effects of brand anthropomorphism", Journal of Consumer Research, Vol. 39 No. 2, pp. 307-323.

Agostini, L., Filippini, R. and Nosella, A. (2015), "Brand-building efforts and their association with SME sales performance", Journal of Small Business Management, Vol. 53 No. 1, pp. 161-173.

Agyapong, A., Ellis, F. and Domeher, D. (2016), "Competitive strategy and performance of family businesses: moderating effect of managerial and innovative capabilities", Journal of Small Business \& Entrepreneurship, Vol. 28 No. 6, pp. 449-477.

Andriotti, F.K. (2010), Intuition in the process of instantaneous decision making. Atelier Doctoral de L'AIMS. Luxemburg: Association Internationale de Management Stratégique.

Antoncic, B., Bratkovic, T., Singh, G. and DeNoble, A. (2015), "The big five personalityentrepreneurship relationship: Evidence from Slovenia", Journal of Small Business Management, Vol. 53, No. 3, pp. 819-841.

Arora, R. and Stoner, C. (2009), "A mixed method approach to understanding brand personality", Journal of Product \& Brand Management, Vol. 18 No. 4, pp.272-283.

Avis, M. (2012), "Brand personality factor based models: a critical review", Ausralasian Marketing Journal, Vol. 20, February, pp. 89-96.

Avis, M. (2014), "The brand personality of rocks", Marketing Theory, Vol. 14 No. 4, pp. 451475.

Azar, S. L. (2015), "Toward an understanding of brand sexual associations", Journal of Product \& Brand Management, Vol. 24 No 1, pp.43-56.

Azoulay, A. and Kapferer, J.K. (2003), "Do brand personality scales really measure brand personality?", Journal of Brand Management, Vol. 11 No. 2, pp. 143-155.

Balmer, J. and Greyser, S. (2006), "Corporate marketing: integrating corporate identity, corporate branding, corporate communications, corporate image and corporate reputation", European Journal of Marketing, Vol. 40 Nos 7-8, pp. 730-741.

Banerjee, S. (2016), "Influence of consumer personality, brand personalilty, and corporate personality on brand preference", Asia Pacific Journal of Marketing, Vol. 28 No. 2, pp. 198216. 
Belk, R.W. (1988), "Possessions and the extended self", Journal of Consumer Research, Vol. 15 No. 2, pp. 139-68.

Bendisch, F., Larsen, G. and Trueman, M. (2007), Branding People: Towards a Conceptual Framework, Bradford University School of Management, Bradford, Working Paper Series $(07 / 22)$.

Bendisch, F., Larsen, G. and Trueman, M. (2013), "Fame and fortune: a conceptual model of CEO brands", European Journal of Marketing, Vol. 47 No. 3-4, pp. 596-614.

Berthon, P., Ewing, M. and Napoli, J. (2008), "Brand management in small to medium-sized enterprises", Journal of Small Business Management, Vol. 46 No. 1, pp. 27-45.

Blombäck, A. and Brunninge, O. (2013), "The dual opening to brand heritage in family businesses", Corporate Communications, Vol. 18 No. 3, pp. 327-346.

Bontour, A. and Lehu, J. (2002), Lifting de Marques, Editions D'Organisation: Paris.

Boyatzis, R. (1998), Transforming Qualitative Information: Thematic Analysis and Code Development, Sage, Thousand Oaks.

Branaghan, R. and Hildebrand, E. (2011), "Brand personality, self-congruity, and preference", Journal of Consumer Behaviour, Vol. 10 No. 5, pp. 304-312.

Bryant, A., and Charmaz, K. (2007), "Introduction: Grounded theory research: methods and practices", in Bryant, A. and Charmaz, K. (Eds.), The Sage handbook of grounded theory, Sage, London, pp. 1-28.

Cardon M.S., Wincent J., Singh J. and Drnovsek, M. (2009). "The nature and experience of entrepreneurial passion", Academy of Management Review, Vol. 34 No. 3, pp. 511-32.

Castrogiovanni, G. (1996), "Pre-startup planning and the survival of new small businesses: theoretical linkages", Journal of Management, Vol. 22 No 6, pp. 801-22.

Centeno, E. and Hart, S. (2012), "The use of communication activities in the development of small-to-medium sized enterprise brands", Marketing Intelligence and Planning, Vol. 30 No. 2, pp. 250-265.

Centeno, E., Hart, S. and Dinnie, K. (2013), "The five phases of SME brand-building", Journal of Brand Management, Vol. 20 No. 6, pp. 445-457.

Charmaz, K. (2011), "Grounded theory methods in social justice research", in Denzin, N.K. and Lincoln, Y.S. (Eds.), The 4th Sage handbook of qualitative research, Sage, Los Angeles, pp. 359-380.

Charmaz, K. (2006), Constructing grounded theory, a practical guide through qualitative analysis, Sage, London.

Chartrand, T.L., Fitzsimons, G.M. and Fitzsimons, G.J. (2008), "Automatic effects of anthropomorphized objects on behavior", Social Cognition, Vol. 26 No. 2, pp. 198-209.

Christmann, H., Alexander, A. and Wood, S. (2016), "Exploring brand identity and entrepreneurship as drivers of small specialist retailer internationalisation", The International Review of Retail, Distribution and Consumer Research, Vol. 26 No. 2, pp. 137-153. 
Cope, J. and Watts, G. (2000), "Learning by doing - an exploration of experience, critical incidents and reflection in entrepreneurial learning", International Journal of Entrepreneurial Behaviour \& Research, Vol. 6 No. 3, pp. 104-124.

Corbin, J., Strauss, A. (1990), "Grounded theory research: procedures, canons, and evaluative criteria”, Qualitative Sociology, Vol. 13, pp. 3-21.

Curran, J. and Blackburn, R. (1994), Small Firms and Local Economic Networks, PCP, London.

Das, G., Kumar Guin, K. and Datta, B. (2012), "Developing brand personality scales: a literature review", The IUP Journal of Brand Management, Vol. IX No. 2, pp. 44-63.

Davies, G. and Chun, R. (2003), "The use of metaphor in the exploration of the brand concept". Journal of Marketing Management, Vol. 19, pp.1-2.

Davies, G., Rojas-Méndez, J.I., Whelan, S., Mete, M. and Loo, T. (2018), "Brand personality: theory and dimensionality", Journal of Product \& Brand Management, Vol. 27 No.2, pp. 115-127.

de Chernatony, L. and M. McDonald (2003), Creating Powerful Brands (Third ed.). Oxford: Elsevier Butterworth-Heinemann.

de Massis, A. and Kotlar, J. (2014), "The case study method in family business research: guidelines for qualitative scholarship", Journal of Family Business Strategy, Vol. 5 No, 1, pp. 15-29.

de Massis, A., Sharma, P., Chua, J., Chrisman, J. and Kotlar, J. (2012), "State-of-the-art of family business research", in de Massis, A., Sharma, P.,Chua, J., Chrisman, J. and Kotlar, J. (Eds.), Family Business Studies: An Annotated Bibliography, Edward Elgar, Northampton, pp. 1046.

Dion, D. and Arnould, E. (2016), "Persona-fied brands: managing branded persons through persona", Journal of Marketing Management, Vol. 32 No. 1-2, pp. 121-148.

Elbanna, S., Child, J. and Dayan, M. (2013), "A Model of Antecedents and Consequences of Intuition in Strategic Decision-making: evidence from Egypt", Long Range Planning, Vol. 46 No. 1-2, pp. 149-176.

Elmuti, D., Khoury, G. and Abdul-Rahim, B. (2011), "Entrepreneur's personality, education and venture effectiveness: perceptions of Palestinian entrepreneurs", Journal of Developmental Entrepreneurship, Vol. 16 No. 2, pp. 251-268.

Endres, A. and Woods, C. (2010), "Schumpeter's 'conduct model of the dynamic entrepreneur': scope and distinctiveness", Journal of Evolutionary Economics, Vol. 20 No. 4, pp. 583-607.

Epley, N., Waytz, A. and Cacioppo, J. (2007), "On seeing human: a three-factor theory of anthropomorphism", Psychological Review, Vol. 114 No. 4, pp. 864-886.

Epley, N., Akalis, S., Waytz, A. and Cacioppo, J.T. (2008), "Creating social connection through inferential reproduction: loneliness and perceived agency in gadgets, Gods, and greyhounds", Psychological Science, Vol. 19 No. 2, pp. 114-120.

Eriksson, P. and Kovalainen, A. (2016), Qualitative Methods in Business Research, Sage, London. 
Escalas, J.E. and Bettman, J.R. (2005), "Self-Construal, reference groups, and brand meaning", Journal of Consumer Research, Vol. 32 No. 3, pp. 378-389.

Flight, R.L. and Coker, K.C. (2016), "Brand constellations: reflections of the emotional self", Journal of Product \& Brand Management, Vol. 25 No. 2, pp.134-147.

Fournier, S. (1998), "Consumers and their brands: developing relationship theory in consumer research", Journal of Consumer Research, Vol. 24 No. 4, pp. 343-353.

Franco, M., Santos, M., Ramalho, I. and Nunes, C. (2014), "An exploratory study of entrepreneurial marketing in SMEs: the role of the founder-entrepreneur", Journal of Small Business and Enterprise Development, Vol. 21 No. 2, pp. 266-283.

Freling, T.H. and Forbes, L.P. (2005), "An empirical analysis of the brand personality effect", The Journal of Product \& Brand Management, Vol. 14 No. 7, pp. 404.

Freling, T.H., Crosno, J.L. and Henard, D.H. (2011), "Brand personality appeal: conceptualization and empirical validation", Journal of the Academy of Marketing Science, Vol. 39, pp. 392-406.

Frese, M. and Gielnik, M. (2014), "The psychology of entrepreneurship", The Annual Review of Organizational Psychology and Organisational Behavior, Vol. 1, pp. 413-438.

Gammoh, B., Mallin, M. and Pullins, E. (2014), "The impact of salesperson-brand personality congruence on salesperson brand identification, motivation and performance outcomes", Journal of Product and Brand Management, Vol. 23 No. 7, pp. 543-553.

Gardner, B.B. and Levy, S.J. (1955), "The product and the brand", Harvard Business Review, March/April, pp. 33-39.

George, B. and Marino, L. (2011), "The epistemology of entrepreneurial orientation: conceptual formation, modeling, and operationalization", Entrepreneurship Theory and Practice, Vol. 35 No. 5, pp. 989-1024.

Gephart, R. (2004), "Qualitative research and the Academy of Management Journal", Academy of Management Journal, Vol. 47, pp. 454-462.

Gibson, B. and Hartman, J. (2014), Rediscovering grounded theory, Sage, London.

Glaser, B., Strauss, A. (1967), The discovery of grounded theory: strategies for qualitative research, Aldine, New York.

Gong, L. (2008), "How social is social responses to computers? The function of the degree of anthropomorphism in computer representations", Computers in Human Behavior, Vol. 24 No. 4, pp. 1494-1509.

Goulding, C. (1998), "Grounded theory: The missing methodology on the interpretivist agenda", Qualitative Market Research: An International Journal, Vol. 1, pp. 50-57.

Grohmann, B. (2009), "Gender dimensions of brand personality", Journal of Marketing Research, Vol. 46 No. 1, pp. 105-119. 
Guido, G. and Peluso, A.M. (2015), "Brand anthropomorphism: conceptualization, measurement, and impact on brand personality and loyalty", Journal of Brand Management, Vol. 22, pp. 119.

Gummesson, E. (2005), "Qualitative research in marketing: Road-map for a wilderness of complexity and unpredictability", European Journal of Marketing, Vol. 39 No. 3-4, pp. 309327.

Guthrie, S.E. (1993), Faces in the clouds, Oxford University Press, New York.

Hanbury, M. (2018), "Here's why Kate Spade didn't profit when her brand sold to Coach for $\$ 2.4$ billion", Business Insider, June 6, website accessed July 9, 2018: http://www.businessinsider.com/why-kate-spade-didnt-profit-when-her-brand-sold-to-coach2018-6.

Hanby, T. (1999), "Brands - dead or alive?: qualitative research for the 21" century; The changing conception of brands", Journal of the Market Research Society, Vol. 41 No.1 pp.18.

Herskovitz, S. and Crystal, M. (2010), "The essential brand pesona: storytelling and branding," Journal of Business Strategy, Vol. 31 No. 3, pp. 21-28.

Hirvonen, S. and Laukkanen, T. (2014), "Brand orientation in small firms: an empirical test of the impact on brand performance", Journal of Strategic Marketing, Vol. 22 No. 1, pp. 41-58.

Hirvonen, S., Laukkanen, T. and Reijonen, H. (2013), "The brand orientation-performance relationship: an examination of moderation effects", Journal of Brand Management, Vol. 20 No. 8, pp. 623-641.

Holland, D. and Garrett, R. (2015), "Entrepreneurs' start-up versus persistence decisions: a critical evaluation of expectancy and value", International Small Business Journal, Vol. 33 No. 2, pp. 194-215.

Horan, G., O’Dwyer, M. and Tiernan, S. (2011), "Exploring management perspectives of branding in service SMEs", Journal of Services Marketing, Vol. 25 No. 2, pp. 114-121.

Huang, H., Mitchell, V. and Rosenaum-Elliott, R. (2012), "Are consumer and brand pesonalities the same?", Psychology \& Marketing, Vol. 29 No. 5, pp. 334-349.

Huber, F., Meyer, F., Vogel, J., Weihrauch, A. and Hamprecht, J. (2013), "Endorser age and stereotypes: consequences on brand age", Journal of Business Research, Vol. 66, pp. 207215.

Hunt, S.D. and Morgan, R.M. (1995), "The comparative advantage theory of competition", Journal of Marketing, Vol. 59 No. 2, pp. 1-15.

Ivens, B. S., Leischnig, A., Muller, B. and Walta, K. (2015), "On the role of brand stereotypes in shaping consumer response toward brands: an empirical examination of direct and mediating effects of warmth and competence", Psychology and Marketing, Vol. 32 No. 8, pp. 808-820.

Jones, O. and Macpherson, A. (2006), "Inter-Organizational Learning and Strategic Renewal in SMEs", Long-Range Planning, Vol. 39, pp. 155-175. 
Kapferer, J. N. (2004), The New Strategic Brand Management: creating and sustaining brand equity long term (Third ed.), London: Kogan Page.

Kaplan, J. and Warren, A. (2010), Patterns of Entrepreneurship Management, John Mill and Sons, Denver, MA.

Keller, K.L. (2001), Building Customer-Based Brand Equity: a Blueprint for Creating Strong Brands, Marketing Science Institute, Cambridge, MA.

Kervyn, N., Fiske, S.T. and Malone, C. (2012), "Brands as intentional agents framework: how perceived intentions and ability can map brand perception", Journal of Consumer Psychology, Vol. 22 No. 2, pp. 166-176.

King, S. (1973), Developing New Brands, Pitman, London.

Kienzler, M. (2017), "Does managerial personality influences pricing practices under uncertainty?", Journal of Product and Brand Management, Vol. 26 No. 7, pp. 734-749.

Kozubíková, L., Belás, J., Bilan, Y., Bartoš, P. (2015), "Personal characteristics of entrepreneurs in the context of perception and management of business risk in the SME segment", Economics and Sociology, Vol. 8 No 1, pp. 41-54.

Krake, F. (2005), "Successful brand management in SMEs: a new theory and practical hints", Journal of Product and Brand Management, Vol. 14 No 4-5, pp. 228-238.

Lam, S.K., Ahearne, M., Mullins, R., Hayati, B. and Schillewaert, N. (2013), "Exploring the dynamics of antecedents to consumer-brand identification with a new brand", Journal of the Academy of Marketing Science, Vol. 41 No. 2, pp. 234-252.

Li, F., Zhou, N., Kashyap, R. and Yang, Z. (2008), "Brand trust as a second-order factor", International Journal of Market Research, Vol. 50 No. 6, pp. 817-839.

Lieven, T. and Hildebrand, C. (2016), "The impact of brand gender on brand equity", International Marketing Review, Vol. 33 No. 2, pp. 178-195.

Lin, L-Y. (2010), "The relationship of consumer personality trait, brand personality and brand loyalty: an empirical study of toys and video games buyers", Journal of Product and Brand Management, Vol. 19 No. 1, pp 4-17.

Lory, M. and McCalman J. (2002), "Management consultancies as brands", Journal of Brand Management, Vol. 9 No. 6, pp. 412-429.

McCracken, G. (1989), "Who is the celebrity endorser? Cultural foundations of the endorsement process", Journal of Consumer Research, Vol. 16, pp. 310-321.

Machado, J., Vacas-de-Carvalho, L., Azar, S. and André, A. (2019), "Brand gender and consumer-based brand equity on Facebook", Journal of Business Research, Vol. 96, pp. 376385.

Maehle, N. and Shneor, R. (2010), "On congruence between brand and human personalities", Journal of Product \& Brand Management, Vol. 19 No. 1, pp. 44-53.

Mäläskä, M., Saraniemib, S. and Juntunenc, M. (2011a), "The corporate branding networks behind B2B SMEs: revealing the actors", paper presented at IMP2011, Markkinoinnin Yksikön Seminaari (Industrial Branding special track). 
Mäläskä, M., Saraniemi, S. and Tähtinen, J. (2011b), "Network actors' participation in B2B SME branding", Industrial Marketing Management, Vol. 40, pp. 1144-1152.

Malhotra, N.K. (1988), "Self concept and product choice: an integrated perspective", Journal of Economic Psychology, Vol. 9 No. 1, pp. 1-28.

Matteucci, X. and Gnoth, J. (2017), "Elaborating on grounded theory in tourism research", Annals of Tourism Research, Vol. 65, pp. 49-59.

McCarthy, B. (2003), "The impact of the entrepreneur's personality on the strategy-formation and planning process in SMEs", Irish Journal of Management, Vol. 24 No. 1, pp. 154-172.

Miles, M.B. and Huberman, A.M. (1994), Qualitative Data Analysis, London, Sage.

Mintzberg, H. and Waters, J. (1985), "Of strategies, deliberate and emergent", Strategic Management Journal, Vol. 6 No. 3, pp. 257-272.

Mitchell, R., Hutchinson, K., Quinn, B. and Gilmore, A. (2015), "A framework for SME retail branding", Journal of Marketing Management, Vol. 31 No. 17-18, pp. 1818-1850.

Muhonen, T., Hirvonen, S. and Laukkanen, T. (2017), "SME brand identity: its components, and performance effects", Journal of Product and Brand Management, Vol. 26 No. 1, pp. 52-67.

Müller, B., Kocher, B. and Crettaz, A. (2013), "The effects of visual rejuvenation through brand logos", Journal of Business Research, Vol. 66, pp. 82-88.

Nida, E.A. and Smalley, W. (1959), Introducing Animism, Friendship, New York, NY.

Niemyjska, A. and Drat-Ruszczak, K. (2013), "When there is nobody, angels begin to fly: supernatural imagery elicited by a loss of social connection", Social Cognition, Vol. 31 No. 1 , pp. 57-71.

Newman, W.H. (1953), "Basic objectives which shape the character of a company", The Journal of Business of the University of Chicago, Vol. 26 No. 4, pp. 211-223.

Odoom, R., Narteh, B. and Boateng, R. (2017), "Branding in SME: current issues and research avenues", Qualitative Market Research: An International Journal, Vol. 20 No. 1, pp. 68-89.

Oguz, F. (2000), "The role of practical knowledge in market processes: an assessment of the Austrian contribution", Journal of Economic \& Social Research, Vol. 2 No. 2, pp. 59-75.

Owens, K., Kirwan, J., Lounsbury, J., Levy, J. and Gibson, L. (2013), "Personality correlates of self-employed small business owners' success", Work, Vol. 45 No. 1, pp. 73-85.

Oyeku, O. M., Oduyoye, O., Asikhia, O., Kabuoh, M. and Elemo G. N. (2014), "On entrepreneurial success of small and medium enterprises (SMEs): a conceptual and theoretical framework", Journal of Economics and Sustainable Development, Vol. 5, pp. 1423.

Parker, B.T. (2009), "A comparison of brand personality and brand user-imagery congruence", Journal of Consumer Marketing, Vol. 26 No. 3, pp.175-184.

Pecot, F., Merchant, A., Valette-Florence, P. and de Barnier, V. (2018), "Cognitive outcomes of brand heritage: A signaling perspective", Journal of Business Research, Vol. 85, pp. 304316. 
Politis, D. (2005), "The process of entrepreneurial learning: a conceptual framework", Entrepreneurship Theory and Practice, Vol. 29 No. 4, pp. 399-424.

Portal, S., Abratt, R. and Bendixen, M. (2018), "Building a human brand: brand anthropomorphism unravelled", Business Horizons, Vol. 61, pp. 367-374.

Powell, E. and Baker, T. (2014), "It's what you make of it: founder identity and enacting strategic responses to adversity", Academy of Management Journal, Vol. 57 No. 5, pp. 1406-1433.

Puzakova, M., Kwak, H. and Rocereto, J. (2009), "Pushing the envelope of brand and personality: antecedents and moderators of anthropomorphized brands", Advances in Consumer Research, Vol. 36, pp. 413-420.

Radler, V.K. (2018), "20 years of brand personality: a bibliometric review and research agenda" Journal of Brand Management, Vol. 25 No. 4, pp. 370-383.

Randhawa, P., Calantone, R.J. and Voorhees, C.M. (2015), "The pursuit of counterfeited luxury: an examination of the negative side effects of close consumer-brand connections," Journal of Business Research, Vol. 68 No. 11, pp. 2395-2403.

Rauschnabel, N. K., Babin, B.J. and Ivens, B.S. (2016), "Brand management in higher education: the University Brand Personality Scale", Journal of Business Research, Vol. 69 No. 8, pp. 3077-3086.

Reijonen, H. (2010), "Do all SMEs practice same kind of marketing?", Journal of Small Business and Enterprise Development, Vol. 17 No. 4, pp. 279-293.

Reijonen, H., Laukkanen, T., Komppula, R. and Tuominen, S. (2012), "Are growing SMEs more market-oriented and brand-oriented?", Journal of Small Business Management, Vol. 50 No. 4, pp. 699-716.

Renton, M., Daellenbach, U., Davenport, S. and James, R. (2016), "Finding fit: an exploratory look at SME brand orientation and brand management in the New Zealand food and beverage sector", Journal of Brand Management, Vol. 23 No. 3, pp. 289-305.

Rode, V. and Vallaster, Ch. (2005), "Corporate branding for start-ups: the crucial role of entrepreneurs", Corporate Reputation Review, Vol. 8 No. 2, p. 121-135.

Shane S. (2000), "Prior knowledge and the discovery of entrepreneurial opportunities", Organization Science, Vol. 11 No. 4, pp. 448-69.

Silverman, D. (2005), Doing Qualitative Research: a Practical Handbook, Sage, London.

Simões, C. and Dibb, S. (2001), "Rethinking the brand concept: the new brand orientation", Corporate Communications, Vol. 6 No. 4, pp. 217-224.

Sirgy, J.M. (1982), "Self-concept in consumer behavior: a critical review", Journal of Consumer Research, Vol. 9 No. 3, pp. 287-300.

Spence, M. and Essoussi, L. (2010), "SME brand building and management: an exploratory study", European Journal of Marketing, Vol. 44 No. 7-8, pp. 1037-1054.

Stern, B. B. (1988), "Literary analysis of the company persona: a speaker schema", Current Issues \& Research in Advertising, Vol. 11 No. 1, pp. 3-20. 
Stinnett, R., Hardy, E. and Waters, R. (2013), "Who are we? The impacts of anthropomorphism and the humanization of nonprofits on brand personality", International Review on Public and Nonprofit Marketing, Vol. 10 No. 1, pp. 31-48.

Strauss, A. and Corbin, L. (1990), Basics of Grounded Theory Methods. Sage, Beverly Hills.

Strauss, A. and Corbin, J. (1998), Basics of Qualitative Research, Sage, London.

Stride, H. and Lee, S. (2007), "No logo? No way. Branding in the non-profit sector", Journal of Marketing Management, Vol.23 No.1-2, pp.107-122.

Sung, Y., and Tinkham, S. (2005), "Brand personality structures in the United States and Korea: common and culture-specific factors", Journal of Consumer Psychology, Vol. 15 No. 4, pp. 334-350.

Sung, Y., Choi, S.M., Ahn, H. and Song, Y. A. (2015), "Dimensions of luxury brand personality: scale development and validation", Psychology and Marketing, Vol. 32 No. 1, pp. 121-132.

Tomczyk, D., Lee, J. and Winslow, E. (2013), "Entrepreneurs' personal values, compensation, and high growth firm performance", Journal of Small Business Management, Vol. 51 No. 1, pp. 66-82.

Törmälä, M. and Gyrd-Jones, R. (2017), "Development of new B2B venture corporate brand identity", Industrial Marketing Management, Vol. 65, pp. 76-85.

Tuškej, U. and Podnar, K. (2018), "Consumers' identification with corporate brands: brand prestige, anthropomorphism and engagement in social media", Journal of Product \& Brand Management, Vol. 27 No.1, pp.3-17.

Veloutsou, C. and Guzmán, F. (2017), "The evolution of brand management thinking over the last 25 years as recorded in the Journal of Product and Brand Management", The Journal of Product \& Brand Management, Vol. 26 No. 1, pp. 2-12.

Veloutsou, C. and Taylor, C.S. (2012), "The role of the brand as a person in business to business brands", Industrial Marketing Management, Vol. 41 No. 6, pp. 898-907.

Verhees, F. and Meulenberg, M. (2004), "Market orientation, innovativeness, product innovation, and performance in small firms", Journal of Small Business Management, Vol. 42 No. 2, pp. 134-154.

Viinikainen, J., Heineck, G., Böckerman, P., Hintsanen, M., Raitakari, O. and Pehkone, J. (2017), "Born entrepreneurs? Adolescents' personality characteristics and entrepreneurship in adulthood", Journal of Business Venturing Insights, Vol. 8, pp. 9-12.

Wang, C. and Chugh, H. (2014), "Entrepreneurial learning: past research and future challenges", International Journal of Management Reviews, Vol. 16 No. 1, pp. 24-61.

Waytz, A., Epley, N. and Cacioppo, J.T. (2010), "Social cognition unbound: insights into anthropomorphism and dehumanization", Current Directions in Psychological Science, Vol. 19 No. 1, pp. 58-62.

Waytz, A., Morewedge, C.K., Epley, N., Monteleone, G., Gao, J.-H. and Cacioppo, J.T. (2010b), "Making sense by making sentient: effectance motivation increases anthropomorphism". Journal of Personality and Social Psychology, Vol. 99 No. 3, pp. 410-435. 
Wijewardena, H., Nanayakkara, G. and de Zoysa, A. (2008), "The owner/manager's mentality and the financial performance of SMEs", Journal of Small Business and Enterprise Development, Vol. 15 No. 1, pp. 150-161.

Wiratmadja, I, Rumanti, A., Reynaldo, R. and Kurniawati, A. (2016), "Intuition concept in small and medium enterprises through stategic decision-making", International Journal of Management and Marketing, Vol. 6 No. 8, pp. 322-326.

Wong, Y. and Merrilees, B. (2005), "A brand orientation typology for SMEs: a case research approach", Journal of Product and Brand Management, Vol. 14 No. 2-3, pp. 155-162.

Yitshaki, R. and Kropp, F. (2016), "Motivations and opportunity recognition of social entrepreneurs", Journal of Small Business Management, Vol. 54 No. 2, pp. 546-565.

Zacca, R., Dayan, M. and Elbanna, S. (2017), "The influence of conflict and intuition on explorative new products and performance in SMEs", Journal of Small Business and Enterprise Development, Vol. 24 No. 4, 2017.

Złotowski, J., Proudfoot, D., Yogeeswaran, K. and Bartneck, C. (2015), "The interactive effects of robot anthropomorphism and robot ability on perceived threat and support for robotics research", International Journal of Social Robotics, Vol. 7, pp. 347-360.

\section{APPENDIX 1 ABOUT HERE}


Table 1. Summary of main supplementary research sources used for the analysis of the pathways of brand-as-a-person

\begin{tabular}{|c|c|}
\hline Pathway & Main supplementary research sources used \\
\hline Brand personality & $\begin{array}{l}\text { - Webpages and print advertising } \\
\text { - Observations before, during, and after interviews }\end{array}$ \\
\hline Tastes and preferences & $\begin{array}{l}\text { - Publicity materials: } \\
* \text { Articles and interviews written by the media. } \\
* \text { Articles and books written by the owner-managers. }\end{array}$ \\
\hline Skills and knowledge & $\begin{array}{l}\text { Publicity materials: } \\
* \text { Articles and interviews written by the media. } \\
* \text { Articles and books written by the owner-managers. } \\
\text { * Videos of lectures and talks given by the owner-managers }\end{array}$ \\
\hline Values & $\begin{array}{l}\text { - Publicity materials: } \\
* \text { Articles and interviews written by the media. } \\
* \text { Articles and books written by the owner-managers. }\end{array}$ \\
\hline
\end{tabular}


Table 2. Main theory and data-driven codes

\begin{tabular}{|l|l|}
\hline \multicolumn{1}{|c|}{ Main Theory-Driven Codes } & \multicolumn{1}{c|}{ Main Data-Driven Codes } \\
\hline Brand-as-a-person & Human characteristics \\
\hline Brand personality traits & Tastes \\
\hline Brand values & Preferences \\
\hline Brand gender & Abilities \\
\hline Influence of the SME owner-manager & Knowledge \\
\hline $\begin{array}{l}\text { Similarities between the personality traits } \\
\text { of the SME owner-manager and the brand }\end{array}$ & Values \\
\hline & Mixed influence of the SME owner-manager \\
\hline & Personification \\
\hline & Brand owner \\
\hline
\end{tabular}




\section{Table 3. Comparisons of the brand personality and the SME owner-manager's personality}

\begin{tabular}{|c|c|c|}
\hline Brand & Brand personality & SME Owner-manager's personality \\
\hline $\begin{array}{l}\text { Interviewee B6 } \\
\text { (health service) }\end{array}$ & $\begin{array}{l}\text { "Willing to serve others; } \\
\text { what this person likes is to } \\
\text { give to others." }\end{array}$ & $\begin{array}{l}\text { "I love to teach other nutritionists what I } \\
\text { know so they can grow, as I have. in my } \\
\text { professional life." }\end{array}$ \\
\hline $\begin{array}{l}\text { Interviewee B12 } \\
\text { (experience } \\
\text { service) }\end{array}$ & $\begin{array}{l}\text { "100 percent happy, fun, } \\
\text { and dynamic." }\end{array}$ & $\begin{array}{l}\text { "It is great to come to work with a big smile, } \\
\text { making everyone laugh, knowing that I am } \\
\text { doing what I love to do." }\end{array}$ \\
\hline $\begin{array}{l}\text { Interviewee B13 } \\
\text { (football clothing } \\
\text { retail) }\end{array}$ & $\begin{array}{l}\text { "Loves football above all; } \\
\text { he is young, dynamic, and } \\
\text { has lots of drive." }\end{array}$ & $\begin{array}{l}\text { "I have played football since I was a boy and I } \\
\text { play it 'religiously' every morning. Aside from } \\
\text { owning this firm and lecturing twice a week at } \\
\text { a university about football management, I } \\
\text { recently finished a master's programme in } \\
\text { football marketing." }\end{array}$ \\
\hline $\begin{array}{l}\text { Interviewee B14 } \\
\text { (multimedia } \\
\text { services) }\end{array}$ & $\begin{array}{l}\text { "Honest, trusting, and } \\
\text { upright." }\end{array}$ & $\begin{array}{l}\text { "I am sort of a media celebrity, well-known } \\
\text { for my honesty and integrity." }\end{array}$ \\
\hline $\begin{array}{l}\text { Interviewee B18 } \\
\text { (coffee shops) }\end{array}$ & $\begin{array}{l}\text { "Courageous and willing to } \\
\text { take risks." }\end{array}$ & $\begin{array}{l}\text { "I was brave enough to launch my first coffee } \\
\text { shop when everyone was telling me that } \\
\text { Starbucks was planning to introduce } 100 \\
\text { shops in one year in Mexico." }\end{array}$ \\
\hline $\begin{array}{l}\text { Interviewee B22 } \\
\text { (Snacks) }\end{array}$ & $\begin{array}{l}\text { "Different, innovative, very } \\
\text { pleasant and intelligent." }\end{array}$ & $\begin{array}{l}\text { "I've always consider myself different, } \\
\text { thinking outside the box.... My parents always } \\
\text { told me I was smart...." }\end{array}$ \\
\hline
\end{tabular}


Table 4. Values of the owner-managers informing the brand and their personal life

\begin{tabular}{|c|c|c|}
\hline Brand & $\begin{array}{l}\text { Values to the brand and its } \\
\text { characteristics as a person }\end{array}$ & Personal values of the SME owner-manager \\
\hline B6 & $\begin{array}{l}\text { "This person is someone who } \\
\text { enjoys helping others and } \\
\text { attempts to make a difference in } \\
\text { their lives." }\end{array}$ & $\begin{array}{l}\text { "I consider myself spiritual and like to help } \\
\text { others." }\end{array}$ \\
\hline $\mathrm{B} 10$ & $\begin{array}{l}\text { "He lives to make bread, to } \\
\text { transmit this tradition to his } \\
\text { family and the rest of his } \\
\text { community." }\end{array}$ & $\begin{array}{l}\text { "I guess I find it important to maintain certain } \\
\text { family traditions." }\end{array}$ \\
\hline B19 & $\begin{array}{l}\text { "Someone who maintains the } \\
\text { culture of beauty and natural } \\
\text { health." }\end{array}$ & $\begin{array}{l}\text { "For many years I have been pushing the } \\
\text { importance of natural products." }\end{array}$ \\
\hline $\mathrm{B} 21$ & $\begin{array}{l}\text { "... she is very responsible and } \\
\text { committed to her family no matter } \\
\text { what, willing to take it all...." }\end{array}$ & $\begin{array}{l}\text { "At home, I learned since I was a little girl to } \\
\text { take on challenges, as my mum had to confront } \\
\text { adversities at all levels and take many risks...." }\end{array}$ \\
\hline $\mathrm{B} 24$ & $\begin{array}{l}\text { "... he considers his independence } \\
\text { and agility important values in his } \\
\text { life...,", }\end{array}$ & $\begin{array}{l}\text { "It has taken so much time to come to this } \\
\text { point where I value my own independence, not } \\
\text { only personal independence, but also } \\
\text { professional independence...." }\end{array}$ \\
\hline B28 & "He values love and kindness..." & $\begin{array}{l}\text { "At this stage in life, what I value most is the } \\
\text { kindness I have received from my family...." }\end{array}$ \\
\hline
\end{tabular}


Appendix 1

\begin{tabular}{|c|c|c|c|c|c|c|c|c|c|c|c|c|c|c|c|}
\hline \multirow[b]{3}{*}{ B } & \multirow{2}{*}{\multicolumn{4}{|c|}{ CHARACTERISTICS OF THE INFORMANT }} & \multicolumn{11}{|c|}{ CHARACTERISTICS OF THE COMPANY } \\
\hline & & & & & \multicolumn{5}{|c|}{ OWNERSHIP } & \multirow{2}{*}{$\begin{array}{c}\text { NUMBER } \\
\text { OF } \\
\text { EMPLOYEES }\end{array}$} & \multicolumn{3}{|c|}{ SECTOR } & \multicolumn{2}{|c|}{$\begin{array}{l}\text { RETAILING } \\
\text { OUTLET }\end{array}$} \\
\hline & Gender & $\begin{array}{l}\text { Formal } \\
\text { Studies }\end{array}$ & $\begin{array}{c}\text { Prior } \\
\text { Years of } \\
\text { Experience }\end{array}$ & $\begin{array}{l}\text { Head of the } \\
\text { Marketing } \\
\text { Department }\end{array}$ & $\begin{array}{c}\text { Number } \\
\text { of Co- } \\
\text { owners }\end{array}$ & $\begin{array}{c}\text { Other } \\
\text { co- } \\
\text { owners } \\
\text { involved } \\
\text { in the } \\
\text { Mgmt. }\end{array}$ & $\begin{array}{c}\text { Family } \\
\text { Business }\end{array}$ & Friends & $\begin{array}{c}\text { Sole } \\
\text { Owner }\end{array}$ & & Manufacture & Services & Retail & $\begin{array}{c}\text { Physical } \\
\text { Retail } \\
\text { Outlet }\end{array}$ & $\begin{array}{l}\text { Online } \\
\text { Retail }\end{array}$ \\
\hline 1 & $\mathrm{M}$ & Engineering & 21 & N/A & 3 & No & $\mathrm{X}$ & & & 25 & $\mathrm{X}$ & & & & \\
\hline 2 & $\mathrm{M}$ & Finance & 8 & $\mathrm{~N} / \mathrm{A}$ & 1 & No & & & $\mathrm{X}$ & 12 & $\mathrm{X}$ & & $\mathrm{X}$ & & $\mathrm{X}$ \\
\hline 3 & $\mathrm{~F}$ & Marketing & 12 & N/A & 1 & No & & & $\mathrm{X}$ & 12 & & $\mathrm{X}$ & $\mathrm{X}$ & $\mathrm{X}$ & \\
\hline 4 & M & Engineering & 15 & Yes & 2 & Yes & $\mathrm{X}$ & & & 50 & & $\mathrm{X}$ & & & \\
\hline 5 & M & Health Sc. & 0 & Yes & 3 & Yes & & $\mathrm{X}$ & & 31 & $\mathrm{X}$ & & $\mathrm{X}$ & $\mathrm{X}$ & $\mathrm{X}$ \\
\hline 6 & $\mathrm{~F}$ & Health Sc. & 0 & N/A & 1 & No & & & $\mathrm{X}$ & 35 & & $\mathrm{X}$ & $\mathrm{X}$ & $\mathrm{X}$ & $\mathrm{X}$ \\
\hline 7 & $\mathrm{M}$ & Engineering & 6 & $\mathrm{~N} / \mathrm{A}$ & 2 & No & & $\mathrm{X}$ & & 19 & $\mathrm{X}$ & & $\mathrm{X}$ & & $\mathrm{X}$ \\
\hline 8 & $\mathrm{~F}$ & Engineering & 5 & $\mathrm{~N} / \mathrm{A}$ & 3 & Yes & $\mathrm{X}$ & & & 100 & $\mathrm{X}$ & & $\mathrm{X}$ & $\mathrm{X}$ & \\
\hline 9 & $\mathrm{M}$ & Engineering & 0 & $\mathrm{~N} / \mathrm{A}$ & 2 & Yes & $\mathrm{X}$ & & & 14 & $\mathrm{X}$ & $\mathrm{X}$ & & & \\
\hline 10 & $\mathrm{M}$ & Business & 23 & $\mathrm{~N} / \mathrm{A}$ & 1 & No & & & $\mathrm{X}$ & 120 & $\mathrm{X}$ & & $\mathrm{X}$ & $\mathrm{X}$ & \\
\hline 11 & $\mathrm{~F}$ & Health Sc. & 3 & $\mathrm{~N} / \mathrm{A}$ & 2 & Yes & $\mathrm{X}$ & & & 13 & $\mathrm{X}$ & & & & \\
\hline 12 & M & $\begin{array}{c}\text { Art } \\
\text { Sciences } \\
\text { and } \\
\text { Business } \\
\end{array}$ & 0 & N/A & 2 & Yes & $\mathrm{X}$ & & & 15 & & $\mathrm{X}$ & $\mathrm{X}$ & & $\mathrm{X}$ \\
\hline 13 & $\mathrm{M}$ & Business & 7 & $\mathrm{~N} / \mathrm{A}$ & 1 & No & & & $\mathrm{X}$ & 14 & $\mathrm{X}$ & & $\mathrm{X}$ & $\mathrm{X}$ & $\mathrm{X}$ \\
\hline 14 & $\mathrm{~F}$ & Marketing & 11 & No & 2 & Yes & $\mathrm{X}$ & & & 14 & $\mathrm{X}$ & $\mathrm{X}$ & $\mathrm{X}$ & & $\mathrm{X}$ \\
\hline 15 & $\mathrm{M}$ & Finance & 26 & N/A & 1 & Yes & & $\mathrm{X}$ & & 180 & $\mathrm{X}$ & $\mathrm{X}$ & $\mathrm{X}$ & $\mathrm{X}$ & \\
\hline
\end{tabular}


Appendix 1 (cont)

\begin{tabular}{|c|c|c|c|c|c|c|c|c|c|c|c|c|c|c|c|}
\hline \multirow{3}{*}{$\begin{array}{l}6 \\
7 \\
8 \\
9 \\
10 \\
11 \\
11 \\
12 \mathbf{B} \\
13 \\
14 \\
\end{array}$} & \multirow{2}{*}{\multicolumn{4}{|c|}{ CHARACTERISTICS OF THE INFORMANT }} & \multicolumn{11}{|c|}{ CHARACTERISTICS OF THE COMPANY } \\
\hline & & & & & \multicolumn{5}{|c|}{ OWNERSHIP } & \multirow{2}{*}{$\begin{array}{c}\text { NUMBER } \\
\text { OF } \\
\text { EMPLOYEES }\end{array}$} & \multicolumn{3}{|c|}{ SECTOR } & \multicolumn{2}{|c|}{$\begin{array}{c}\text { RETAILING } \\
\text { OUTLET }\end{array}$} \\
\hline & Gender & $\begin{array}{l}\text { Formal } \\
\text { Studies }\end{array}$ & $\begin{array}{l}\text { Prior Years of } \\
\text { Experience }\end{array}$ & $\begin{array}{c}\text { Head of the } \\
\text { Marketing } \\
\text { Department }\end{array}$ & $\begin{array}{c}\text { Number } \\
\text { of Co- } \\
\text { owners }\end{array}$ & $\begin{array}{l}\text { Other } \\
\text { co- } \\
\text { owners } \\
\text { involved } \\
\text { in the } \\
\text { Mgmt. } \\
\end{array}$ & $\begin{array}{c}\text { Family } \\
\text { Business }\end{array}$ & Friends & $\begin{array}{c}\text { Sole } \\
\text { Owner }\end{array}$ & & Manufacture & Services & Retail & $\begin{array}{c}\text { Physical } \\
\text { Retail } \\
\text { Outlet }\end{array}$ & $\begin{array}{l}\text { Online } \\
\text { Retail }\end{array}$ \\
\hline $16^{16}$ & $\mathrm{~F}$ & Business & 2 & N/A & 2 & No & $\mathrm{X}$ & & & 12 & $\mathrm{X}$ & & $\mathrm{X}$ & $\mathrm{X}$ & \\
\hline 1818 & M & Engineering & 7 & No & 3 & Yes & $\mathrm{X}$ & & & 140 & $\mathrm{X}$ & & $\mathrm{X}$ & $\mathrm{X}$ & \\
\hline 2019 & M & High-school & 0 & No & 4 & Yes & & $\mathrm{X}$ & & 220 & $\mathrm{X}$ & & $\mathrm{X}$ & & $\mathrm{X}$ \\
\hline 20 & $\mathrm{~F}$ & Marketing & 0 & No & 2 & No & $\mathrm{X}$ & & & 47 & $\mathrm{X}$ & & & & \\
\hline $23^{21}$ & $\mathrm{~F}$ & High-school & 2 & N/A & 2 & No & $\mathrm{X}$ & & & 12 & $\mathrm{X}$ & & & & \\
\hline 242 & M & Engineering & 0 & N/A & 2 & Yes & $\mathrm{X}$ & & & 23 & $\mathrm{X}$ & & & & \\
\hline 253 & M & Business & 0 & N/A & 2 & Yes & $\mathrm{X}$ & & & 60 & & $\mathrm{X}$ & $\mathrm{X}$ & $\mathrm{X}$ & \\
\hline 2724 & M & Business & 0 & N/A & 1 & No & & & $\mathrm{X}$ & 54 & & $\mathrm{X}$ & $\mathrm{X}$ & & $\mathrm{X}$ \\
\hline $\mathrm{BO}_{26}$ & $\mathrm{M}$ & Business & 5 & N/A & 2 & Yes & $\mathrm{X}$ & & & 53 & $\mathrm{X}$ & & $\mathrm{X}$ & $\mathrm{X}$ & \\
\hline 327 & M & High-school & 0 & N/A & 5 & Yes & & $\mathrm{X}$ & & 46 & $\mathrm{X}$ & & $\mathrm{X}$ & $\mathrm{X}$ & \\
\hline 328 & M & Business & 0 & N/A & 2 & Yes & $\mathrm{X}$ & & & 61 & $\mathrm{X}$ & & $\mathrm{X}$ & $\mathrm{X}$ & \\
\hline 3529 & M & Art Science & 0 & N/A & 1 & No & & & $\mathrm{X}$ & 15 & $\mathrm{X}$ & & & & \\
\hline$\beta 630$ & $\mathrm{~F}$ & Art Science & 0 & N/A & 2 & Yes & & $\mathrm{X}$ & & 12 & $\mathrm{X}$ & & & & \\
\hline
\end{tabular}

